Published in final edited form as:

Curr Top Membr. 2014 ; 73: 205-232. doi:10.1016/B978-0-12-800223-0.00005-0.

\title{
Organic Anion Transporting Polypeptides
}

\author{
Bruno Stieger and \\ University Hospital, Department of Clinical Pharmacology and Toxicology, 8091 Zürich, \\ Switzerland \\ Bruno Hagenbuch \\ Department of Pharmacology, Toxicology and Therapeutics, The University of Kansas Medical \\ Center, Kansas City, Kansas 66160, United States \\ Bruno Stieger: bstieger@kpt.uzh.ch; Bruno Hagenbuch: bhagenbuch@kumc.edu
}

\section{Abstract}

Organic anion transporting polypeptides or OATPs are central transporters in the disposition of drugs and other xenobiotics. In addition, they mediate transport of a wide variety of endogenous substrates. The critical role of OATPs in drug disposition has spurred research both in academia and in the pharmaceutical industry. Translational aspects with clinical questions are the focus in academia, while the pharmaceutical industry tries to define and understand the role these transporters play in pharmacotherapy. The present overview summarizes our knowledge on the interaction of food constituents with OATPs, and on the OATP transport mechanisms. Further, it gives an update on the available information on the structure-function relationship of the OATPs, and finally, covers the transcriptional and posttranscriptional regulation of OATPs.

\section{Introduction}

The liver and the kidney are the two most important organs in the metabolism and excretion of xenobiotics such as drugs or toxins. In addition, the liver constitutes - after the gut wall a second barrier for the entry of xenobiotics into the systemic circulation. It has been known for a long time that certain toxins like phalloidin (from the death cap Amanita phalloides) are organ specific. The liver-specific toxicity of phalloidin has been attributed to a transport system mediating the uptake of this toxin into hepatocytes (Frimmer, 1982). It was found in the perfused rat liver that adding silymarin shortly after phallodin exposure leads to an attenuation of the toxic effect of phalloidin as assessed by potassium efflux from the perfused liver (Weil \& Frimmer, 1970). Uptake experiments into isolated rat hepatocytes lead to the postulation of a transport system accepting the bile acid cholate, the cholecystographic agent iodipamide and antamanide, which is another toxin from $A$. phalloides (Petzinger, Joppen, \& Frimmer, 1983). This postulated transport system was thought to differ from the transport system responsible for the hepatocellular uptake of bromosulfophthalein (BSP) based on inhibition experiments (Petzinger, et al., 1983). Subsequently, this transport system was postulated to be a "multispecific organic anion transporter" (Frimmer \& Ziegler, 1988; Ziegler, Frimmer, \& Fasold, 1984). Of note, earlier studies on perfused rat liver by a different group provided evidence for a common uptake mechanism for bilirubin, BSP and indocyanine green that could not be inhibited by glycocholic acid (Scharschmidt, Waggoner, \& Berk, 1975). Studies in kidneys demonstrated 
even earlier that the handling of organic acids and organic bases differs (Lotspeich, 1958), again pointing to the presence of more than one transport system. Hence, by the early to mid-eighties, the stage was set for concepts that functionally discriminated transporters for organic anions from transporters for organic cations (reviewed in (van Montfoort et al., 2003).

The method of expression cloning was introduced for transporters by following the uptake activity for the substrate of interest. This lead to the molecular identification of the intestinal sodium-dependent uptake system for D-glucose (SGLT1) (Hediger, Coady, Ikeda, \& Wright, 1987). Using BSP as a lead-substrate in conjunction with measurement of chloride dependent transport activity (Min, Johansen, Campbell, \& Wolkoff, 1991), investigators cloned the first sodium-independent organic anion transporter (rOATP1A1) from a rat liver cDNA library (Jacquemin, Hagenbuch, Stieger, Wolkoff, \& Meier, 1994). In addition to the organic anion BSP, this transporter could also mediate the sodium-independent transport of taurocholate and cholate, but independently from chloride. It very soon became clear that rOATP1A1 had to have closely related homologues (Hagenbuch, Scharschmidt, \& Meier, 1996), and this lead to the identification of rOATP1A4 by homology screening of a rat brain cDNA library (B. Noe, Hagenbuch, Stieger, \& Meier, 1997). Functional characterization of rOATP1A1 (Bossuyt, Muller, Hagenbuch, \& Meier, 1996) and rOATP1A4 (B. Noe, et al., 1997), as well as of their human homolog hOATP1A2 (Bossuyt, Muller, \& Meier, 1996) demonstrated their broad substrate specificity and revealed the ability of OATPs to transport drugs.

Today, more than 300 members of the OATP (SLCO) transporter superfamily with 11 OATPs expressed in humans are known (Hagenbuch \& Stieger, 2013). In a human genome wide meta-analysis of genes correlating with total serum bilirubin levels, an additional human OATP (hOATP1B7 (formerly SLC21A21 or LST-3TM12) was among other proteins identified to be associated with higher bilirubin levels. In contrast, in another genome-wide association study, hOATP1B7 was not associated with elevated bilirubin levels (Buch et al., 2010). Importantly, this hOATP1B7 has not been reported to be a functionally active OATP so far. Nevertheless, in an analysis of tissue specific expression of various solute transporters in rats, $\mathrm{OOATP1B7}$ was reported to be highly expressed at the mRNA level exclusively in rat liver (Sreedharan, Stephansson, Schioth, \& Fredriksson, 2011). Given the lack of a reported function of hOATP1B7, SLCO1B7 may be a pseudogene.

Substrates of OATPs constitute endogenous molecules, food constituents, drugs and toxins (Table 1) as summarized in multiple recent reviews (Hagenbuch \& Gui, 2008; Hagenbuch \& Stieger, 2013; Kalliokoski \& Niemi, 2009; Konig, 2011; Kusuhara \& Sugiyama, 2009; Roth, Obaidat, \& Hagenbuch, 2012; Shitara et al., 2013). The importance of OATPs in drug disposition is now widely accepted, and interactions with OATPs are tested during drug development by the pharmaceutical industry as requested by regulatory authorities (Fenner et al., 2012; Giacomini et al., 2010; S. M. Huang et al., 2008; Tweedie et al., 2013; L. Zhang, Huang, \& Lesko, 2011; L. Zhang, Strong, Qiu, Lesko, \& Huang, 2006; L. Zhang, Zhang, Strong, Reynolds, \& Huang, 2008). OATPs were identified on their basis to transport BSP, a substrate which was thought to be transported (in part) by a postulated bilirubin transport system (Clarenburg \& Kao, 1973; Scharschmidt, et al., 1975). Many 
years after their identification it was indeed demonstrated that hOATP1B1 and hOATP1B3 could mediate bilirubin transport (Briz, Serrano, MacIas, Gonzalez-Gallego, \& Marin, 2003; Cui, Konig, Leier, Buchholz, \& Keppler, 2001). Furthermore, it was also realized that selected OATPs play a central role in the disposition of drugs in humans. More importantly, identifying OATPs has also significantly contributed to an understanding of the molecular mechanisms of pharmacokinetic drug-drug interactions (Konig, Muller, \& Fromm, 2013; Shitara, et al., 2013)

\section{Transport of natural products by OATPs}

Besides the well-established transporter-mediated drug-drug interactions that occur in cases where a transporter either mediates the uptake of two interacting drugs, or where the uptake of one drug is inhibited by the interacting drug, transporter-mediated food-drug interactions have recently become a focus in the field of drug disposition. In particular, polyphenols like flavonoids, which are found in numerous dietary components, fruit juices and green tea have been studied as potential perpetrators of OATP-mediated drug uptake (Bailey, Dresser, Leake, \& Kim, 2007; Dolton, Roufogalis, \& McLachlan, 2012; Fuchikami et al., 2006; X. Wang, Wolkoff, \& Morris, 2005). Most of these studies investigated to what extent such dietary components would affect OATP-mediated substrate transport. In 2002, it was demonstrated that grapefruit, orange and apple juice could inhibit OATP-mediated fexofenadine uptake (Dresser et al., 2002). In follow-up studies, the same group showed that grapefruit juice reduced the oral bioavailability of fexofenadine in healthy human volunteers, possible by inhibiting hOATP1A2-mediated fexofenadine uptake in the small intestine (Glaeser et al., 2007). Furthermore, they showed that naringin - a component of grapefruit juice - was able to inhibit completely fexofenadine transport mediated by hOATP1A2 expressed in HeLa cells (Bailey, et al., 2007). Besides inhibiting fexofenadine transport, naringin also inhibited talinolol transport in hOATP1A2-expressing Xenopus laevis oocytes (Shirasaka et al., 2010), and hOATP1A2-mediated uptake of pravastatin and pitavastatin (Shirasaka, Suzuki, Shichiri, Nakanishi, \& Tamai, 2011). Naringin also inhibited hOATP2B1-mediated uptake of pitavastatin, but did not affect pravastatin transport by hOATP2B1 (Shirasaka, et al., 2011). The inhibition of OATP-mediated BSP transport by the flavonoids apigenin, kaempferol and quercetin was reported to be of competitive nature for intestinal hOATP1A2 and hOATP2B1 (Mandery et al., 2010), as well as for the liver expressed hOATP1B1 and hOATP1B3 (Mandery et al., 2012). A standardized extract of milk thistle seeds (silymarin) contains several flavonolignans including silibinin, and has been used to treat liver disease since the $16^{\text {th }}$ century. Legalon SIL is a drug that contains the two diastereomers silibinin A and silibinin B (also known as silybin A and silybin B) and is used as an antidote for acute amatoxin poisoning (Mengs, Pohl, \& Mitchell, 2012). In addition, high dose intravenous silibinin is currently investigated in clinical trials for the treatment of hepatitis C infections (Ferenci et al., 2008). It was shown in 2006 that silibinin inhibits hOATP1B3-mediated uptake of amanitin into hOATP1B3-expressing MDCKII cells (Letschert, Faulstich, Keller, \& Keppler, 2006). Two recent studies further characterized the interactions of silymarin and some of its major constituents with respect to inhibition of OATP-mediated uptake (Kock, Xie, Hawke, Oberlies, \& Brouwer, 2013; Wlcek, Koller, Ferenci, \& Stieger, 2013). In these studies 
silbinin inhibited OATP-mediated substrate uptake. Kock et al. (2013) determined IC $_{50}$ values for silymarin and three of its major constituents, namely silybin A, silybin B and silychristin, on hOATP1B1- and hOATP1B3-mediated estradiol-17 $\beta$-glucuronide and hOATP2B1-mediated estrone-3-sulfate uptake. Silybin A and silybin B inhibited OATPmediated substrate uptake with $\mathrm{IC}_{50}$ values in the low micromolar range (Kock, et al., 2013). For hOATP1B3- and hOATP2B1-mediated uptake of estrone-3-sulfate, silibinin was a competitive inhibitor with $\mathrm{K}_{\mathrm{i}}$ values of $5 \mu \mathrm{M}$ for hOATP1B3 and 3.6 $\mu \mathrm{M}$ for hOATP2B1 (Wlcek, et al., 2013). However, no direct uptake of any of these flavonoids by any OATP has yet been demonstrated.

Another family of flavonoids that have been studied extensively because of their potential beneficial effects on the cardiovascular system (Moore, Jackson, \& Minihane, 2009), aging (Khurana, Venkataraman, Hollingsworth, Piche, \& Tai, 2013) and cancer (Singh, Shankar, $\&$ Srivastava, 2011) are the green tea catechins, such as epicatechin gallate (ECG) and epigallocatechin gallate (EGCG). Both these catechins are modulators of OATP-mediated transport (Roth, Timmermann, \& Hagenbuch, 2011). ECG and EGCG inhibited the uptake of estrone-3-sulfate mediated by hOATP1A2, hOATP1B1 and hOATP2B1 while EGCG stimulated estrone-3-sulfate uptake of hOATP1B3. IC $_{50}$ values for the two compounds ranged from about 10 to $100 \mu \mathrm{M}$. Direct transport experiments performed with OATPexpressing CHO cells (for hOATP1B1, hOATP1B3 and hOATP2B1) or HEK293 cells (for hOATP1A2) revealed that both ECG, as well as EGCG, are transported substrates of hOATP1A2 and hOATP1B3 (Roth, et al., 2011). The signals for hOATP1B1 were not significantly higher than the control cells. Kinetic experiments demonstrated saturable uptake of ECG and EGCG by hOATP1A2 and hOATP1B3 with $\mathrm{K}_{\mathrm{m}}$ values between 10 and $39 \mu \mathrm{M}$ (Roth, et al., 2011). These transport data were later confirmed using cytotoxicity experiments where incubation of control $\mathrm{CHO}$ cells or $\mathrm{CHO}$ cells expressing hOATP1B1 and hOATP1B3 with increasing concentrations of EGCG for 48 hours killed the hOATP1B1- and hOATP1B3-expressing cells with $\mathrm{IC}_{50}$ values of 7.7 and $3.2 \mu \mathrm{M}$, respectively as compared to $271 \mu \mathrm{M}$ for wild-type $\mathrm{CHO}$ cells (Y. Zhang et al., 2013). The same study also demonstrated that quercetin-3-gallate and three additional synthetic quercetin derivatives preferentially killed $\mathrm{CHO}$ cells that expressed hOATP1B1 or hOATP1B3, data consistent with these quercetin derivatives acting as substrates of hOATP1B1 and hOATP1B3 (Y. Zhang, et al., 2013). However, additional studies using cell lines expressing individual OATPs are required to determine which of the interacting flavonoids indeed are substrates of the respective OATPs.

\section{Transport Mechanisms of OATPs}

\section{OATPs as anion exchangers}

OATPs tend to transport amphipathic molecules with a molecular weight of more than 350 Da (Roth, et al., 2012). Furthermore, they are capable of mediating the transport of a tightly albumin bound substance like bilirubin. Hence, the transport mechanism of OATPs should involve the binding of generally amphipathic or even rather hydrophobic substrates followed by a translocation process across the plasma membrane. In the case of bilirubin, this process most likely involves binding and transport of a molecule with two negative charges because 
the pKa of both carboxylic groups is most likely below 5.0 (Vega-Hissi, Estrada, Lavecchia, \& Pis Diez, 2013), even though others hypothesized that it may be above 8.0 (Mukerjee \& Ostrow, 2010). Regardless of this discussion on the protonation state of bilirubin at physiologic pH, BSP is a dianionic molecule. Furthermore, many OATP substrates are anions (Roth, et al., 2012). Consequently, transporting anionic OATP substrates across the membrane involves the movement of one or two negative charges against a negative membrane potential of about $-35 \mathrm{mV}$ in hepatocytes (Boyer, Graf, \& Meier, 1992). This process is energetically unfavorable and not very likely to occur. To date, the transport mechanism(s) of OATPs is not known in detail. However, a considerable body of evidence supporting an anion-exchange transport mechanism has accumulated. Bicarbonate was the first anion to be identified, and can act as a counter ion of rOATP1A1. In HeLa cells expressing rOATP1A1, uptake of taurocholate was demonstrated to occur in exchange for bicarbonate (Satlin, Amin, \& Wolkoff, 1997). Subsequently, trans-stimulation of uptake of taurocholate and leukotriene by glutathione was demonstrated for rOATP1A1 (L. Li, Lee, Meier, \& Ballatori, 1998). rOATP1A1, and rOATP1A4, mediated uptake of taurocholate was trans-stimulated by preloading X. laevis oocytes with taurocholate (L. Li, Meier, \& Ballatori, 2000). In the same study, intracellular glutathione stimulated uptake of the uncharged digoxin via rOATP1A4, suggesting a rather complex transport mechanism for this OATP. Interestingly, S-(2,4-dinitrophenyl)-glutathione (DNP-SG) only stimulated taurocholate uptake mediated by rOATP1A4 but not taurocholate uptake mediated by rOATP1A1 (L. Li, et al., 2000). In addition, only rOATP1A4 mediated efflux of this glutathione conjugate. In this context, it should be kept in mind that digoxin is a substrate for rOATP1A4 but not for rOATP1A1 (B. Noe, et al., 1997). Using isolated membrane vesicles with defined sidedness from HeLa cells expressing rOATP1A1, investigators demonstrated asymmetric glutathione transport (Mittur, Wolkoff, \& Kaplowitz, 2002). Uptake into inside-out membrane vesicles (representing glutathione efflux from intact cells) was 2- to 3-fold higher than in right-side out vesicles (Mittur, et al., 2002). Furthermore, this transport activity was insensitive to changes in the membrane potential. A report suggesting that bile acids are cotransported with glutathione by hOATP1B3 (Briz et al., 2006) could not be confirmed by others (Mahagita, Grassl, Piyachaturawat, \& Ballatori, 2007). This is in agreement with the fact that substrate transport by hOATP2B1 could not be stimulated by glutathione (Nozawa, Imai, Nezu, Tsuji, \& Tamai, 2004). More recently, a study testing various OATPs in stably transfected cell lines found substrate-mediated bicarbonate efflux for all 5 transporters investigated (Leuthold et al., 2009). Hence, current evidence supports the concept that OATPs in general work as organic anion exchangers with bicarbonate likely being a physiologic counterion. This exchange process has not been characterized extensively at a molecular level like reconstituted transporters in liposomes. To the best of our knowledge, there is only one publication so far that describes the electrophysiologic characterization of OATPs. In this study the authors found that in X. laevis oocytes expressing either hOATP1B1 or hOATP1B3 a current across the membrane could be recorded in the presence of different OATP substrates, indicating a net movement of a negative charge into the oocytes (Martinez-Becerra et al., 2011). 


\section{Binding sites of OATPs}

While no information of the architecture of the substrate binding site(s) of any OATP is currently available, there exists considerable evidence for OATPs having multiple binding sites. Kinetic analysis of the transport of estrone-3-sulfate by hOATP1B1 revealed both a high and a low affinity transport activity, while the same transporter revealed simple Michaelis-Menten kinetics for estradiol-17 $\beta$-glucuronide (Tamai et al., 2001). Similarly, transport of estrone-3-sulfate by hOATP2B1 expressed in X. laevis oocytes has two binding sites (Shirasaka, Mori, Shichiri, Nakanishi, \& Tamai, 2012), while when expressed in HEK-293 cells only one binding site was reported (Tamai, et al., 2001). This discrepancy was explained by a difference in expression levels, although the potential impact of different expression systems (amphibian versus mammalian cells) was not ruled out. Two binding sites for estrone-3-sulfate on hOATP1B1 were later independently confirmed (Gui \& Hagenbuch, 2009; J. Noe, Portmann, Brun, \& Funk, 2007). Recently, different binding sites of hOATP4C1 for estrone-3-sulfate and digoxin were reported (Yamaguchi et al., 2010). Bovine OATP1A2 was also reported, in contrast to hOATP1A2, to have two binding sites for estrone-3-sulfate (X. Liu et al., 2013).

Additional evidence for the presence of more than one binding site on OATPs was obtained from inhibition experiments and reported first for rOATP1A4, which showed a stimulation of taurocholate transport by estradiol-17 $\beta$-glucuronide. However, taurocholate did not stimulate the transport of the substrate digoxin (D. Sugiyama, Kusuhara, Shitara, Abe, \& Sugiyama, 2002). Among the human OATPs, hOATP2B1-mediated dehydroepiandrosterone sulfate transport could be increased by co-addition of prostaglandin A1 or prostaglandin A2 (Pizzagalli et al., 2003). Low progesterone also stimulated hOATP2B1-mediated etrone-3-sulfate transport, but interestingly, at higher progesterone concentrations this stimulation was attenuated, demonstrating a biphasic action of progesterone (Grube et al., 2006). The same study found classic inhibition of hOATP2B1mediated estrone-3-sulfate transport by other steroids, namely testosterone and mifepristone. However, testosterone has recently been reported to stimulate hOATP2B1 (Karlgren et al., 2012). Some dietary components like the flavonoid rutin stimulated transport of dehydroepiandrosterone sulfate by hOATP1B1, while other flavonoids like biochanin A or luteolin acted as inhibitors (X. Wang, et al., 2005). hOATP1B3 transport activity can also be stimulated by green tea extracts or epigallocatechin as measured by estron-3-sulfate uptake (Roth, et al., 2011). Silbinin has recently been tested with several human organic anion transporters, and found to be a classic inhibitor of the high affinity estrone-3-sulfate binding site of hOATP1B1. The low affinity binding site was stimulated at low silibininconcentrations and inhibited at high silibinin concentrations (Wlcek, et al., 2013). Finally, the classic drug and PXR agonist clotrimazole stimulated hOATP1B3-, but not hOATP1B1mediated estradiol-17 $\beta$-glucuronide transport (Gui et al., 2008). Most interestingly, in the same study, clotrimazole did not affect the hOATP1B3-mediated transport of estrone-3sulfate and inhibited fluo-3 uptake. As an additional modulating drug, fendiline stimulated hOATPB2B1-mediated estrone-3-sulfate transport (Karlgren, et al., 2012). 


\section{Modulation of transport activity}

According to in vitro experiments, the transport activity of hOATP2B1, which is expressed in the small intestine and many other organs, is stimulated by an extracellular acidic milieu (Kobayashi et al., 2003). Based on an investigation of the $\mathrm{pH}$ dependence of 13 rat and human OATPs, all but hOATP1C1 were stimulated by an acidic extracellular $\mathrm{pH}$ (Leuthold, et al., 2009). Of note, this stimulation was substrate dependent. For example, while hOATP2B1-mediated uptake of prostaglandin $\mathrm{E}_{2}$ was not stimulated by an extracellular low $\mathrm{pH}$, transport of thyroxine increased at low pH (Leuthold, et al., 2009). Similarly, hOATP2B1-mediated pemetrexed transport was strongly stimulated by an acidic $\mathrm{pH}$, while this was not the case for BSP (Visentin, Chang, Romero, Zhao, \& Goldman, 2012). Along these lines, hOATP1B1-meditiated transport was also stimulated in a substrate-dependent manner at an acidic $\mathrm{pH}$, and may be due to the presence of two different binding sites on this transporter (Leuthold, et al., 2009). However, other reasons cannot be excluded. Of note, different statins when tested as hOATP2B1 substrates show also a variable response to extracellular pH (Varma et al., 2011). Kinetic characterization of five OATPs revealed a significantly increased affinity or a trend towards increased affinity at low pH (Leuthold, et al., 2009). Mutating a highly conserved histidine in the third transmembrane (TM) domain of rOATP1A1 to a glutamine found at the same position in hOATP1C1 abolished $\mathrm{pH}$ sensitivity of transport, while the reverse replacement in hOATP1C1 converted this transporter into a pH-sensitive transporter (Leuthold, et al., 2009). Comparing the effect of different $\mathrm{pH}$ gradients across the cell membrane on the transport activity of rOATP1A1, revealed that transport stimulation was not proportional to the magnitude of the $\mathrm{pH}$ gradient and the authors suggested a $\mathrm{pH}$-dependent modification of the protonation state of the intracellular portion of the transporter (Marin et al., 2003).

Overall, a detailed mechanistic understanding of the transport mechanism(s) and driving forces for OATPs is currently lacking. There is however, evidence that OATPs have a rather complex transport mechanism, and many (if not most of them) have more than one binding site. In addition, the extracellular $\mathrm{pH}$ dependence of OATPs, as seen in the acidic microclimate in the small intestine (Daniel, Fett, \& Kratz, 1989) may mean that they are modulated in vivo by nearby acid extruders, such as $\mathrm{Na}^{+} / \mathrm{H}^{+}$-exchangers. Consequently, in vitro experiments aimed at determining substrate specificities of OATPs expressed in an acidic environment should be performed at acidic and neutral $\mathrm{pH}$.

\section{Structural information on OATPs}

\section{General structure}

Given that all mammalian OATPs (650 to 700 amino acids) have an amino-acid sequence identity of more than $30 \%$ to their more distant relatives (Hagenbuch \& Meier, 2003), it is highly likely that they all share the same overall TM domain structure. Initial hydrophobicity analysis of rOATP1A1 and hOATP1A2 predicted the presence of 10 to 12 TM domains with both $\mathrm{N}$ - and C-terminal ends on the cytoplasmic side (Jacquemin, et al., 1994; Kullak-Ublick et al., 1995). The intracellular localization of the C-terminal end was experimentally confirmed using an antibody against the C-terminal end of hOATP1B3. Immunostaining was only observed in detergent permeabilized cells (Abe et al., 2001), 
confirming a topology with both termini on the cytoplasmic side of the membrane. In 2008, the 12 TM domain structure of rOATP1A1 was confirmed using site-directed mutagenesis of putative N-glycosylation sites (P. Wang, Hata, Xiao, Murray, \& Wolkoff, 2008). It was demonstrated that rOATP1A1 was N-glycosylated in the second and fifth extracellular loop, and that the unglycosylated protein was retained intracellularly and thus caused reduced transport function (P. Wang, et al., 2008). Similar results were recently published for hOATP1B1 (Yao et al., 2012). The authors demonstrated that hOATP1B1 is N-glycosylated in the second and fifth extracellular loop, and that the unlgycosylated protein is retained in the endoplasmic reticulum. Thus, it is likely that all mammalian OATPs are $\mathrm{N}$-glycosylated in these two extracellular loops. Disulfide bonds can also have an effect on the proper folding and function of a protein. Based on results from site-directed mutagenesis of the 10 conserved cysteine residues in the large extracellular loop 5 of hOATP2B1, all 10 cysteine residues are normally disulfide bonded and these disulfide bonds are important for the proper targeting of hOATP2B1 to the plasma membrane (Hanggi, Grundschober, Leuthold, Meier, \& St-Pierre, 2006).

\section{Role of conserved amino acids}

In the absence of a crystal structure for any of the OATPs, homology modeling has been performed by several groups and the respective models were used to test structural hypotheses. The first of such models was described in 2005 and predicted the presence of a central pore in hOATP1B3 and hOATP2B1 that contained several positively charged arginine, lysine and histidine residues (Meier-Abt, Mokrab, \& Mizuguchi, 2005). The role of some of these conserved positively charge amino acids was then tested in site-directed mutagenesis studies using hOATP1B1 (Weaver \& Hagenbuch, 2010) and hOATP1B3 (Glaeser, Mandery, Sticht, Fromm, \& Konig, 2010; Mandery et al., 2011) as a template. In hOATP1B1, mutations at R57, K361 and R580 all decreased the affinity for estradiol-17 $\beta$ glucuronide and increased the affinity for BSP, suggesting that these amino acid residues are part of the substrate binding sites. Mutations of the intracellular K90, H92 and R93 mainly affected the maximal transport activity. Mutants R181K and R580A also reduced surface expression of hOATP1B1 (Weaver \& Hagenbuch, 2010). K41, K361 and R580 are important for substrate transport of hOATP1B3 (Glaeser, et al., 2010; Mandery, et al., 2011) while K399 is necessary for normal surface expression (Mandery, et al., 2011). Because hOATP1B1 and hOATP1B3 have overlapping substrate specificities, it is interesting to note that both K361 and R580 are important for the transport function of both hOATP1B1 and hOATP1B3.

\section{Individual transmembrane domains}

According to several studies, certain amino acids in TM domains 2, 6, 8, 9 and 10 are important for the function of hOATP1B1 (Gui \& Hagenbuch, 2009; J. Huang et al., 2013; N. Li et al., 2012; Miyagawa, Maeda, Aoyama, \& Sugiyama, 2009) and hOATP1B3 (Gui \& Hagenbuch, 2008). In TM2, charged amino acids D70 and E74 seem critical for estrone-3sulfate transport (N. Li, et al., 2012). While D70 seems to decrease both high- and lowaffinity estron-3-sulfate uptake, E74 seems only important for high-affinity transport. In addition, mutant G76A showed reduced protein expression when compared to wild-type hOATP1B1 and the other mutants (N. Li, et al., 2012). The effect of two tryptophan residues 
within the OATP family signature at the extracellular half of TM6 of hOATP1B1 was tested by mutating the tryptophan to alanine residues, and the effect of these mutations on estrone-3-sulfate transport was tested. While wild-type hOATP1B1 has a high- and a lowaffinity binding site for estrone-3-sulfate resulting in biphasic kinetics (Gui \& Hagenbuch, 2009; J. Noe, et al., 2007; Tamai, et al., 2001), the W258A mutant showed only a single binding component with a $\mathrm{K}_{\mathrm{m}}$ value in between the high- and low-affinity values of wildtype hOATP1B1 (J. Huang, et al., 2013). In contrast, the W259A mutant retained biphasic kinetics for estrone-3-sulfate with a higher $\mathrm{K}_{\mathrm{m}}$ value for the high-affinity but a similar $\mathrm{K}_{\mathrm{m}}$ value for the low-affinity component as compared to wild-type hOATP1B1 (J. Huang, et al., 2013). Several groups utilized a chimera approach and constructed chimeras using hOATP1B1 and hOATP1B3 (Degorter, Ho, Leake, Tirona, \& Kim, 2012; Gui \& Hagenbuch, 2008, 2009; Miyagawa, et al., 2009). Replacing TM8 in hOATP1B1 with that of hOATP1B3 resulted in a protein with an 18-fold higher $\mathrm{K}_{\mathrm{m}}$ value for estrone-3-sulfate than that of wild-type hOATP1B1 and abolished estradiol-17 $\beta$-glucuronide transport (Miyagawa, et al., 2009). Replacing TM9 in hOATP1B1 with that of hOATP1B3 did not change the transport of estradiol-17 $\beta$-glucuronide, but increased the $\mathrm{K}_{\mathrm{m}}$ value for estron-3sulfate 7.4-fold (Miyagawa, et al., 2009). TM10 was identified as being important for substrate transport in both hOATP1B1 (Gui \& Hagenbuch, 2009) and hOATP1B3 (Gui \& Hagenbuch, 2008). Follow-up site-directed mutagenesis studies identified several amino acids (L545, F546, L550 and S554) within TM10 that when replaced with the hOATP1B3 counterparts converted hOATP1B1 from a biphasic to a monophasic estron-3-sulfate transporter (Gui \& Hagenbuch, 2009). Similar experiments with hOATP1B3 resulted in the identification of Y537, S545 and T550 in TM10 as being important for the hOATP1B3 selective substrate CCK-8 (Gui \& Hagenbuch, 2008). Finally, in a recent report, hOATP1B1 was converted into an hOATP1B3-like transporter that was able to transport CCK-8 when the three amino acid residues A45 in TM1, L545 in TM10 and T615 in extracellular loop 6 were replaced by the corresponding hOATP1B3 residues (Degorter, et al., 2012). Although this triple mutant showed uptake of CCK-8, its intrinsic clearance was about 8-fold smaller than the intrinsic clearance of hOATP1B3.

Taken together, available data are consistent with OATPs being 12TM domain proteins with both termini on the cytoplasmic side. Furthermore, OATPs seem to have an aqueous pore that can accept several substrates with overlapping and partially distinct binding sites, which consist in part of conserved positively charged amino acids. Future experiments using higher resolution homology modeling will help to better delineate the location of functionally important amino acid residues until the three-dimensional structure has been elucidated either using crystallography and/or NMR spectroscopy. In addition, the current hypothetical models will have to be improved by investigating which amino acid residues within the postulated TM domains are accessible from the outside or the inside in the absence or presence of substrates. 


\section{Regulation of OATPs}

\section{Transcriptional regulation of OATPs}

Regulation of gene expression at the transcriptional level for adaptive purposes is governed by transcription factors, which act as sensors for endogenous ligands and xenobiotics (Germain, Staels, Dacquet, Spedding, \& Laudet, 2006). Hence, at the level of the intact organism, transcriptional regulation of gene expression can be studied by applying xenobiotics to animal models and then analyzing the expression of genes of interest. Such studies were performed with knockout mice lacking the genes for nuclear receptors and demonstrated that expression of SLCOS can be up-regulated by ligands for the arylhydrocarbon receptor AhR, the constitutive androgen receptor CAR, the pregnane $\mathrm{X}$ receptor PXR and the farnesoid X receptor FXR (Klaassen \& Aleksunes, 2010; Meyer zu Schwabedissen \& Kim, 2009). However, such studies do not demonstrate that the transcription factors investigated bind directly to the gene of interest. Liver-enriched transcription factors (Schrem, Klempnauer, \& Borlak, 2002) belong to different classes of transcriptional regulators. They are also called hepatocyte nuclear factors and are known to positively or negatively regulate the transcription of $S L C O$ genes (reviewed in (Geier, Wagner, Dietrich, \& Trauner, 2007; Hagenbuch \& Stieger, 2013; Klaassen \& Aleksunes, 2010; Stieger \& Geier, 2011; Svoboda, Riha, Wlcek, Jaeger, \& Thalhammer, 2011)).

The bile acid sensor FXR can directly and indirectly modulate the expression of SLCO genes, leading either to up-regulation or to down-regulation of gene transcription of the respective genes (Eloranta \& Kullak-Ublick, 2008; Godoy et al., 2013). Such studies may also lead to conflicting results. Expression of $S L C O 1 B 1$ was reported to be reduced via FXR-dependent repression of HNF-1 (Jung, Elferink, Stellaard, \& Groothuis, 2007), and increased via direct up-regulation by FXR (Meyer Zu Schwabedissen et al., 2010). Other nuclear receptors like PXR, CAR and LXR are also known to regulate the expression of SLCO genes. (Godoy, et al., 2013; Hagenbuch \& Stieger, 2013; Klaassen \& Aleksunes, 2010). Lately, the vitamin D receptor VDR has been added to this list, and it has been shown to activate the expression of SLCO1A2 (Eloranta, Hiller, Juttner, \& Kullak-Ublick, 2012). As ligands for nuclear receptors are also substrates for OATPs (Gui, et al., 2008), the transporters may, to some extent, control the access of nuclear receptor ligands to their own genes. Hypoxia leads to the expression of hypoxia-inducible factors, which in turn regulate transcription (Schodel, Mole, \& Ratcliffe, 2013). Interestingly, a cancer-specific variant of hOATP1B3 was found to be induced by hypoxia and a promoter construct of SLCOIB3 was demonstrated to bind HIF-1a (Han, Kim, Thakkar, Kim, \& Lee, 2013). Another research group identified two functional HIF-response elements in the promoter of SLCOIB3 (Ramachandran et al., 2013).

Tissue-specific regulation of protein expression is frequently associated with epigenetic regulation. In mice, a genome-wide DNA-methylation profiling revealed CpG dinucleotides in the area of the transcriptional start site of hOATP1B2 (Imai et al., 2009). An extension of this analysis revealed $\mathrm{CpG}$ islands around the translation start sites of mOATP1A1, mOATP1A6, mOATP1C1 and mOATP1A4; comparable findings were obtained for hOATP1B1 and hOATP1B3 (Imai, Kikuchi, Kusuhara, \& Sugiyama, 2013). The different 
methylation patterns are suggested to be involved in the tissue-specific expression of the investigated OATPs. In Caco- 2 cells, heterochromatin protein $1 \beta$ up-regulation leads to an up-regulation of SLCO1B3 among other targets (Tell, Wang, Blunier, \& Benya, 2011). Expression of a cancer-specific variant of hOATP1B3 in various cancer cell lines is critically dependent on the methylation pattern around the translational start site (Imai et al., 2013), as well as the expression of SLCO2Al in human head and neck squamous cell carcinoma (Zolk et al., 2013).

\section{Posttranslational regulation of OATPs}

At the post-transcriptional level, ATP-induced functional down-regulation of rOATP1A1 is mediated by serine phosphorylation (Glavy, Wu, Wang, Orr, \& Wolkoff, 2000). This phosphorylation is not associated with subsequent internalization of rOATP1A1. In a subsequent study, S634 and S635 of rOATP1A1 were found to be phosphorylated (Xiao, Nieves, Angeletti, Orr, \& Wolkoff, 2006). This study was extended to rOATP1A4 in X. laevis oocytes, where PKC-dependent inhibition of transport activity of rOATP1A1 and rOATP1A4 was observed (Guo \& Klaassen, 2001). Plasma membrane expression of hOATP1B1 in COS7 and HEK293 cells on the other hand, was stimulated after treatment of the cells with 8-Br-cAMP and this stimulation could be blocked by protein kinase Ainhibitors (Sun, Ponamgi, Boyer, \& Suchy, 2008). Using protein kinase A inhibitors alone, plasma membrane expression of hOATP1B1 was reduced. In contrast, hOATP2B1 stably transfected in MDCK cells could be phosphorylated in a protein kinase C-dependent manner, thereby leading to a rapid internalization of hOATP2B1 (Kock et al., 2010). hOATP1A2 expressed in COS-7 cells was also internalized from the plasma membrane in a protein kinase C-dependent manner by a process requiring ongoing clathrin-dependent endocytosis (Zhou, Lee, Krafczyk, Zhu, \& Murray, 2011). According to a recent paper, short-term treatment of either Caco- 2 cells or rats with amiodarone leads to an increased surface expression of hOATP2B1 in Caco-2 cells and of rOATP2B1 at the brush border membrane of rat jejunum and ileum as assessed by Western blotting (Segawa et al., 2013).

\section{Scaffolding of OATPs}

Protein-protein interactions leading to scaffolds at the plasma membrane can also be considered a posttranslational regulatory mechanism. A yeast two-hybrid screen using the C-terminus of various drug transporters indeed revealed an interaction of hOATP1A2, hOATP1C1 and hOATP3A1 with PDZ proteins (Kato, Yoshida, Watanabe, Sai, \& Tsuji, 2004). PDZ adaptors are well known to be involved in the regulation of transport proteins by regulating their plasma membrane expression level (Sugiura, Shimizu, Kijima, Minakata, \& Kato, 2011). rOATP1A1 was shown in a cell-culture system in conjunction with coimmunoprecipitation to interact with PDZK1 (P. Wang et al., 2005). Most interestingly, mice with a disrupted gene for PDZK1 showed a strongly reduced expression of mOATP1A1 at the hepatocyte basolateral membrane, with an increased cytoplasmic localization of mOATP1A1 (P. Wang, et al., 2005). These mice display a slightly reduced fractional uptake rate for the prototypic OATP substrate BSP and about a $25 \%$ increased plasma half-life (P. Wang, et al., 2005). PDZK1 mediates the trafficking to the plasma membrane by a selective recruitment of microtubule-based motor proteins (W. J. Wang, Murray, \& Wolkoff, 2013). Others found a reduced estrone-3-sulfate uptake into the portal 
vein of mice lacking PDZK1 without a change in systemic circulation (Sugiura et al., 2010). Using an Ussing-chamber setup with small intestine from the same mice, uptake of estrone-3-sulfate from the apical lumen into intestinal tissue was significantly reduced. This study confirmed and found interactions of the C-terminus of mouse OATPs with different PDZ proteins (Sugiura, et al., 2010). Interactions of human and mouse OATPs with the different adaptor proteins are summarized in Table 2 (Sugiura, et al., 2010).

In summary, OATPs are extensively regulated at the transcriptional and posttranscriptional levels. Given that many OATPs are xenobiotic transporters and hence involved in the disposition and elimination of potentially toxic xenotiotics, this extensive network of regulatory processes acting on OATPs may contribute to protect organisms from toxic actions of xenobiotics. Regulation of gene expression by xenosensors like the nuclear receptors CAR or PXR is key in the detoxification of xenobiotics by metabolizing as well as exporting them for excretion. Hence, common transcriptional regulatory mechanisms for OATPs as cellular xenobiotic uptake systems with down-stream metabolism and metabolite export is an effective functional network preventing cells from being overloaded with potentially harmful compounds.

Although single nucleotide polymorphisms are not in a strict sense a regulatory mechanism because they cannot be modified by cells, there is now ample evidence that polymorphic variants of OATPs are abundant in humans and may contribute significantly to changes in drug disposition. They also constitute risk factors for adverse drug actions. This topic has lately been extensively reviewed (Clarke \& Cherrington, 2012; Gong \& Kim, 2013; Hagenbuch \& Stieger, 2013; Nakanishi \& Tamai, 2012; Niemi, 2010; Niemi, Pasanen, \& Neuvonen, 2011; Shitara, et al., 2013; Stieger \& Meier, 2011; Zair, Eloranta, Stieger, \& Kullak-Ublick, 2008).

\section{Outlook}

The role of OATPs in drug and xenobiotic disposition is now well established and accepted (Fenner, et al., 2012). Due to their wide expression in most tissues, they govern the access (or exit) of many endogenous and exogenous compounds in a vast variety of cell types and associated tissues and organs. Lately, the importance of transporters, including OATPs, to monitoring organ function and to visualize them has been prominently recognized (Hoekstra et al., 2013; Stieger, Heger, de Graaf, Paumgartner, \& van Gulik, 2012; Van Beers, Pastor, $\&$ Hussain, 2012). Imaging is widely used to diagnose and manage a variety of diseases including neurologic disorders or cancer. Because OATPs are found to be expressed in many different cancers (Cutler \& Choo, 2011; Obaidat, Roth, \& Hagenbuch, 2012; Sissung, Reece, Spencer, \& Figg, 2012), they are an important diagnostic marker.. They may also be used as entry sites for drugs used to fight cancer (T. Liu \& Li, 2013) an important aspect that certainly has a large potential for further anticancer drug development. As OATPs are very important in drug disposition, direct determination of their transport activity in vivo is highly desirable. With the rapid progress in the development of better imaging tools such as positron emission tomography or single-photon emission computed tomography (Mairinger, Erker, Muller, \& Langer, 2011; Y. Sugiyama \& Yamashita, 2011), such a goal should be achievable. In order to successfully develop novel OATP substrates to be used for in vivo 
transporter function determination, a tight coordination of studies performed in vitro (e.g. by using heterologous expression systems) and in vivo experiments will be necessary, whereby special consideration has to be given to the overlapping substrate specificity of OATPs. As OATPs are also the entry sites for toxins, (e.g. the ones present in the mushroom death cap), there potential as drug target for the treatment of patients after ingestion of toxic substances could certainly be further developed. Because drug effects and adverse drug actions critically depend on the intracellular drug concentrations (Chu et al., 2013), a major effort has to be made in elucidating the exact transport mechanism as well as the potential driving forces of OATPs. This knowledge will be critical for better understanding and potentially even predicting cellular effects of drugs. Lastly, there is currently no information about the high-resolution structure of OATPs available. Such information is critical for understanding the molecular transport mechanisms of OATPs. The emergence of new tools like cryoelectronmicroscopy (Milne et al., 2013), and its integration with structure determination by NMR or x-ray crystallography will advance this challenging area of OATP research.

\section{Acknowledgments}

Bruno Stieger is supported by Grant \# 310030_144195 / 1 from the Swiss National Science Foundation. Bruno Hagenbuch is supported by National Institutes of Health Grants RR021940 and GM077336.

\section{References}

Abe T, Unno M, Onogawa T, Tokui T, Kondo TN, Nakagomi R, et al. LST-2, a human liver-specific organic anion transporter, determines methotrexate sensitivity in gastrointestinal cancers. Gastroenterology. 2001; 120(7):1689-1699. [PubMed: 11375950]

Bailey DG, Dresser GK, Leake BF, Kim RB. Naringin is a major and selective clinical inhibitor of organic anion-transporting polypeptide 1A2 (OATP1A2) in grapefruit juice. Clin Pharmacol Ther. 2007; 81(4):495-502. [PubMed: 17301733]

Bossuyt X, Muller M, Hagenbuch B, Meier PJ. Polyspecific drug and steroid clearance by an organic anion transporter of mammalian liver. J Pharmacol Exp Ther. 1996; 276(3):891-896. [PubMed: 8786566]

Bossuyt X, Muller M, Meier PJ. Multispecific amphipathic substrate transport by an organic anion transporter of human liver. J Hepatol. 1996; 25(5):733-738. [PubMed: 8938553]

Boyer JL, Graf J, Meier PJ. Hepatic transport systems regulating pHi, cell volume, and bile secretion. Annu Rev Physiol. 1992; 54:415-438. [PubMed: 1562181]

Briz O, Romero MR, Martinez-Becerra P, Macias RI, Perez MJ, Jimenez F, et al. OATP8/1B3mediated cotransport of bile acids and glutathione: an export pathway for organic anions from hepatocytes? J Biol Chem. 2006; 281(41):30326-30335. [PubMed: 16877380]

Briz O, Serrano MA, MacIas RI, Gonzalez-Gallego J, Marin JJ. Role of organic anion-transporting polypeptides, OATP-A, OATP-C and OATP-8, in the human placenta-maternal liver tandem excretory pathway for foetal bilirubin. Biochem J. 2003; 371(Pt 3):897-905. [PubMed: 12568656]

Brouwer KL, Keppler D, Hoffmaster KA, Bow DA, Cheng Y, Lai Y, et al. In vitro methods to support transporter evaluation in drug discovery and development. Clin Pharmacol Ther. 2013; 94(1):95112. [PubMed: 23588315]

Buch S, Schafmayer C, Volzke H, Seeger M, Miquel JF, Sookoian SC, et al. Loci from a genome-wide analysis of bilirubin levels are associated with gallstone risk and composition. Gastroenterology. 2010; 139(6):1942-1951. e1942. [PubMed: 20837016]

Chu X, Korzekwa K, Elsby R, Fenner K, Galetin A, Lai Y, et al. Intracellular drug concentrations and transporters: measurement, modeling, and implications for the liver. Clin Pharmacol Ther. 2013; 94(1):126-141. [PubMed: 23588320] 
Clarenburg R, Kao CC. Shared and separate pathways for biliary excretion of bilirubin and BSP in rats. Am J Physiol. 1973; 225(1):192-200. [PubMed: 4714401]

Clarke JD, Cherrington NJ. Genetics or environment in drug transport: the case of organic anion transporting polypeptides and adverse drug reactions. Expert Opin Drug Metab Toxicol. 2012; 8(3):349-360. [PubMed: 22280100]

Cui Y, Konig J, Leier I, Buchholz U, Keppler D. Hepatic uptake of bilirubin and its conjugates by the human organic anion transporter SLC21A6. J Biol Chem. 2001; 276(13):9626-9630. [PubMed: 11134001]

Cutler MJ, Choo EF. Overview of SLC22A and SLCO families of drug uptake transporters in the context of cancer treatments. Curr Drug Metab. 2011; 12(8):793-807. [PubMed: 21787263]

Daniel H, Fett C, Kratz A. Demonstration and modification of intervillous pH profiles in rat small intestine in vitro. Am J Physiol. 1989; 257(4 Pt 1):G489-495. [PubMed: 2552822]

Degorter MK, Ho RH, Leake BF, Tirona RG, Kim RB. Interaction of Three Regiospecific Amino Acid Residues Is Required for OATP1B1 Gain of OATP1B3 Substrate Specificity. Mol Pharm. 2012; 9(4):986-995. [PubMed: 22352740]

Dolton MJ, Roufogalis BD, McLachlan AJ. Fruit juices as perpetrators of drug interactions: the role of organic anion-transporting polypeptides. Clin Pharmacol Ther. 2012; 92(5):622-630. [PubMed: 23033114]

Dresser GK, Bailey DG, Leake BF, Schwarz UI, Dawson PA, Freeman DJ, et al. Fruit juices inhibit organic anion transporting polypeptide-mediated drug uptake to decrease the oral availability of fexofenadine. Clin Pharmacol Ther. 2002; 71(1):11-20. [PubMed: 11823753]

Eloranta JJ, Hiller C, Juttner M, Kullak-Ublick GA. The SLCO1A2 gene, encoding human organic anion-transporting polypeptide $1 \mathrm{~A} 2$, is transactivated by the vitamin D receptor. Mol Pharmacol. 2012; 82(1):37-46. [PubMed: 22474172]

Eloranta JJ, Kullak-Ublick GA. The role of FXR in disorders of bile acid homeostasis. Physiology (Bethesda). 2008; 23:286-295. [PubMed: 18927204]

Fenner KS, Jones HM, Ullah M, Kempshall S, Dickins M, Lai Y, et al. The evolution of the OATP hepatic uptake transport protein family in DMPK sciences: from obscure liver transporters to key determinants of hepatobiliary clearance. Xenobiotica. 2012; 42(1):28-45. [PubMed: 22077101]

Ferenci P, Scherzer TM, Kerschner H, Rutter K, Beinhardt S, Hofer H, et al. Silibinin is a potent antiviral agent in patients with chronic hepatitis $\mathrm{C}$ not responding to pegylated interferon/ribavirin therapy. Gastroenterology. 2008; 135(5):1561-1567. [PubMed: 18771667]

Frimmer M. Organotropism by carrier-mediated transport. Trends Pharmacol Sci. 1982; 3:395-397.

Frimmer M, Ziegler K. The transport of bile acids in liver cells. Biochim Biophys Acta. 1988; 947(1): 75-99. [PubMed: 3278743]

Fuchikami H, Satoh H, Tsujimoto M, Ohdo S, Ohtani H, Sawada Y. Effects of herbal extracts on the function of human organic anion-transporting polypeptide OATP-B. Drug Metab Dispos. 2006; 34(4):577-582. [PubMed: 16415120]

Geier A, Wagner M, Dietrich CG, Trauner M. Principles of hepatic organic anion transporter regulation during cholestasis, inflammation and liver regeneration. Biochim Biophys Acta. 2007; 1773(3):283-308. [PubMed: 17291602]

Germain P, Staels B, Dacquet C, Spedding M, Laudet V. Overview of nomenclature of nuclear receptors. Pharmacol Rev. 2006; 58(4):685-704. [PubMed: 17132848]

Giacomini KM, Huang SM, Tweedie DJ, Benet LZ, Brouwer KL, Chu X, et al. Membrane transporters in drug development. Nat Rev Drug Discov. 2010; 9(3):215-236. [PubMed: 20190787]

Glaeser H, Bailey DG, Dresser GK, Gregor JC, Schwarz UI, McGrath JS, et al. Intestinal drug transporter expression and the impact of grapefruit juice in humans. Clin Pharmacol Ther. 2007; 81(3):362-370. [PubMed: 17215845]

Glaeser H, Mandery K, Sticht H, Fromm MF, Konig J. Relevance of conserved lysine and arginine residues in transmembrane helices for the transport activity of organic anion transporting polypeptide 1B3. Br J Pharmacol. 2010; 159(3):698-708. [PubMed: 20100277]

Glavy JS, Wu SM, Wang PJ, Orr GA, Wolkoff AW. Down-regulation by extracellular ATP of rat hepatocyte organic anion transport is mediated by serine phosphorylation of oatp1. J Biol Chem. 2000; 275(2):1479-1484. [PubMed: 10625701] 
Godoy P, Hewitt NJ, Albrecht U, Andersen ME, Ansari N, Bhattacharya S, et al. Recent advances in $2 \mathrm{D}$ and $3 \mathrm{D}$ in vitro systems using primary hepatocytes, alternative hepatocyte sources and nonparenchymal liver cells and their use in investigating mechanisms of hepatotoxicity, cell signaling and ADME. Arch Toxicol. 2013; 87(8):1315-1530. [PubMed: 23974980]

Gong IY, Kim RB. Impact of genetic variation in OATP transporters to drug disposition and response. Drug Metab Pharmacokinet. 2013; 28(1):4-18. [PubMed: 23047721]

Grube M, Kock K, Karner S, Reuther S, Ritter CA, Jedlitschky G, et al. Modification of OATP2B1mediated transport by steroid hormones. Mol Pharmacol. 2006; 70(5):1735-1741. [PubMed: 16908597]

Gui C, Hagenbuch B. Amino acid residues in transmembrane domain 10 of organic anion transporting polypeptide 1B3 are critical for cholecystokinin octapeptide transport. Biochemistry. 2008; 47(35): 9090-9097. [PubMed: 18690707]

Gui C, Hagenbuch B. Role of transmembrane domain 10 for the function of organic anion transporting polypeptide 1B1. Protein Sci. 2009; 18(11):2298-2306. [PubMed: 19760661]

Gui C, Miao Y, Thompson L, Wahlgren B, Mock M, Stieger B, et al. Effect of pregnane X receptor ligands on transport mediated by human OATP1B1 and OATP1B3. Eur J Pharmacol. 2008; 584(1):57-65. [PubMed: 18321482]

Guo GL, Klaassen CD. Protein kinase C suppresses rat organic anion transporting polypeptide 1- and 2-mediated uptake. J Pharmacol Exp Ther. 2001; 299(2):551-557. [PubMed: 11602666]

Hagenbuch B, Gui C. Xenobiotic transporters of the human organic anion transporting polypeptides (OATP) family. Xenobiotica. 2008; 38(7-8):778-801. [PubMed: 18668430]

Hagenbuch B, Meier PJ. The superfamily of organic anion transporting polypeptides. Biochim Biophys Acta. 2003; 1609(1):1-18. [PubMed: 12507753]

Hagenbuch B, Scharschmidt BF, Meier PJ. Effect of antisense oligonucleotides on the expression of hepatocellular bile acid and organic anion uptake systems in Xenopus laevis oocytes. Biochem J. 1996; 316(Pt 3):901-904. [PubMed: 8670169]

Hagenbuch B, Stieger B. The SLCO (former SLC21) superfamily of transporters. Mol Aspects Med. 2013; 34(2-3):396-412. [PubMed: 23506880]

Han S, Kim K, Thakkar N, Kim D, Lee W. Role of hypoxia inducible factor-1alpha in the regulation of the cancer-specific variant of organic anion transporting polypeptide 1B3 (OATP1B3), in colon and pancreatic cancer. Biochem Pharmacol. 2013; 86(6):816-823. [PubMed: 23924606]

Hanggi E, Grundschober AF, Leuthold S, Meier PJ, St-Pierre MV. Functional analysis of the extracellular cysteine residues in the human organic anion transporting polypeptide, OATP2B1. Mol Pharmacol. 2006; 70(3):806-817. [PubMed: 16754786]

Hediger MA, Coady MJ, Ikeda TS, Wright EM. Expression cloning and cDNA sequencing of the Na+l glucose co-transporter. Nature. 1987; 330(6146):379-381. [PubMed: 2446136]

Hoekstra LT, De Graaf W, Nibourg GAA, Heger M, Bennink RJ, Stieger B, et al. Physiological and biochemical basis of clinical liver function tests: a review. Ann Surg. 2013; 257:27-36. [PubMed: 22836216]

Huang J, Li N, Hong W, Zhan K, Yu X, Huang H, et al. Conserved Tryptophan Residues within Putative Transmembrane Domain 6 Affect Transport Function of Organic Anion Transporting Polypeptide 1B1. Mol Pharmacol. 2013; 84(4):521-527. [PubMed: 23858103]

Huang SM, Strong JM, Zhang L, Reynolds KS, Nallani S, Temple R, et al. New era in drug interaction evaluation: US Food and Drug Administration update on CYP enzymes, transporters, and the guidance process. J Clin Pharmacol. 2008; 48(6):662-670. [PubMed: 18378963]

Imai S, Kikuchi R, Kusuhara H, Sugiyama Y. DNA methylation and histone modification profiles of mouse organic anion transporting polypeptides. Drug Metab Dispos. 2013; 41(1):72-78. [PubMed: 23033256]

Imai S, Kikuchi R, Kusuhara H, Yagi S, Shiota K, Sugiyama Y. Analysis of DNA methylation and histone modification profiles of liver-specific transporters. Mol Pharmacol. 2009; 75(3):568-576. [PubMed: 19047482]

Imai S, Kikuchi R, Tsuruya Y, Naoi S, Nishida S, Kusuhara H, et al. Epigenetic Regulation of Organic Anion Transporting Polypeptide 1B3 in Cancer Cell Lines. Pharm Res. 2013 
Jacquemin E, Hagenbuch B, Stieger B, Wolkoff AW, Meier PJ. Expression cloning of a rat liver $\mathrm{Na}(+)$-independent organic anion transporter. Proc Natl Acad Sci U S A. 1994; 91(1):133-137. [PubMed: 8278353]

Jung D, Elferink MG, Stellaard F, Groothuis GM. Analysis of bile acid-induced regulation of FXR target genes in human liver slices. Liver Int. 2007; 27(1):137-144. [PubMed: 17241392]

Kalliokoski A, Niemi M. Impact of OATP transporters on pharmacokinetics. Br J Pharmacol. 2009; 158(3):693-705. [PubMed: 19785645]

Karlgren M, Vildhede A, Norinder U, Wisniewski JR, Kimoto E, Lai Y, et al. Classification of inhibitors of hepatic organic anion transporting polypeptides (OATPs): influence of protein expression on drug-drug interactions. J Med Chem. 2012; 55(10):4740-4763. [PubMed: 22541068]

Kato Y, Yoshida K, Watanabe C, Sai Y, Tsuji A. Screening of the interaction between xenobiotic transporters and PDZ proteins. Pharm Res. 2004; 21(10):1886-1894. [PubMed: 15553237]

Khurana S, Venkataraman K, Hollingsworth A, Piche M, Tai TC. Polyphenols: benefits to the cardiovascular system in health and in aging. Nutrients. 2013; 5(10):3779-3827. [PubMed: 24077237]

Klaassen CD, Aleksunes LM. Xenobiotic, bile acid, and cholesterol transporters: function and regulation. Pharmacol Rev. 2010; 62(1):1-96. [PubMed: 20103563]

Kobayashi D, Nozawa T, Imai K, Nezu J, Tsuji A, Tamai I. Involvement of human organic anion transporting polypeptide OATP-B (SLC21A9) in pH-dependent transport across intestinal apical membrane. J Pharmacol Exp Ther. 2003; 306:703-708. [PubMed: 12724351]

Kock K, Koenen A, Giese B, Fraunholz M, May K, Siegmund W, et al. Rapid modulation of the organic anion transporting polypeptide 2B1 (OATP2B1, SLCO2B1) function by protein kinase Cmediated internalization. J Biol Chem. 2010; 285(15):11336-11347. [PubMed: 20159975]

Kock K, Xie Y, Hawke RL, Oberlies NH, Brouwer KL. Interaction of silymarin flavonolignans with organic anion-transporting polypeptides. Drug Metab Dispos. 2013; 41(5):958-965. [PubMed: 23401473]

Konig J. Uptake transporters of the human OATP family. Molecular characteristics, substrates, their role in drug-drug interactions, and functional consequences of polymorphisms. Handb Exp Pharmacol. 2011; 201:1-28. [PubMed: 21103967]

Konig J, Muller F, Fromm MF. Transporters and drug-drug interactions: important determinants of drug disposition and effects. Pharmacol Rev. 2013; 65(3):944-966. [PubMed: 23686349]

Kullak-Ublick GA, Hagenbuch B, Stieger B, Schteingart CD, Hofmann AF, Wolkoff AW, et al. Molecular and functional characterization of an organic anion transporting polypeptide cloned from human liver. Gastroenterology. 1995; 109:1274-1282. [PubMed: 7557095]

Kusuhara H, Sugiyama Y. In vitro-in vivo extrapolation of transporter-mediated clearance in the liver and kidney. Drug Metab Pharmacokinet. 2009; 24(1):37-52. [PubMed: 19252335]

Letschert K, Faulstich H, Keller D, Keppler D. Molecular characterization and inhibition of amanitin uptake into human hepatocytes. Toxicol Sci. 2006; 91(1):140-149. [PubMed: 16495352]

Leuthold S, Hagenbuch B, Mohebbi N, Wagner CA, Meier PJ, Stieger B. Mechanisms of pH-gradient driven transport mediated by organic anion polypeptide transporters. Am J Physiol Cell Physiol. 2009; 296(3):C570-582. [PubMed: 19129463]

Li L, Lee TK, Meier PJ, Ballatori N. Identification of glutathione as a driving force and leukotriene C4 as a substrate for oatp1, the hepatic sinusoidal organic solute transporter. J Biol Chem. 1998; 273(26):16184-16191. [PubMed: 9632674]

Li L, Meier PJ, Ballatori N. Oatp2 mediates bidirectional organic solute transport: a role for intracellular glutathione. Mol Pharmacol. 2000; 58(2):335-340. [PubMed: 10908301]

Li N, Hong W, Huang H, Lu H, Lin G, Hong M. Identification of amino acids essential for estrone-3sulfate transport within transmembrane domain 2 of organic anion transporting polypeptide $1 \mathrm{~B} 1$. PLoS One. 2012; 7(5):e36647. [PubMed: 22574206]

Liu T, Li Q. Organic anion-transporting polypeptides: a novel approach for cancer therapy. J Drug Target. 2013 
Liu X, Huang J, Sun Y, Zhan K, Zhang Z, Hong M. Identification of multiple binding sites for substrate transport in bovine organic anion transporting polypeptide 1a2. Drug Metab Dispos. 2013; 41(3):602-607. [PubMed: 23255551]

Lotspeich WD. Kidney, water and electrolyte metabolism. Annu Rev Physiol. 1958; 20:339-376. [PubMed: 13521754]

Mahagita C, Grassl SM, Piyachaturawat P, Ballatori N. Human organic anion transporter 1B1 and 1B3 function as bidirectional carriers and do not mediate GSH-bile acid cotransport. Am J Physiol Gastrointest Liver Physiol. 2007; 293(1):G271-278. [PubMed: 17412826]

Mairinger S, Erker T, Muller M, Langer O. PET and SPECT radiotracers to assess function and expression of ABC transporters in vivo. Curr Drug Metab. 2011; 12(8):774-792. [PubMed: 21434859]

Mandery K, Balk B, Bujok K, Schmidt I, Fromm MF, Glaeser H. Inhibition of hepatic uptake transporters by flavonoids. Eur J Pharm Sci. 2012; 46(1-2):79-85. [PubMed: 22394605]

Mandery K, Bujok K, Schmidt I, Keiser M, Siegmund W, Balk B, et al. Influence of the flavonoids apigenin, kaempferol, and quercetin on the function of organic anion transporting polypeptides 1A2 and 2B1. Biochem Pharmacol. 2010; 80(11):1746-1753. [PubMed: 20797388]

Mandery K, Sticht H, Bujok K, Schmidt I, Fahrmayr C, Balk B, et al. Functional and structural relevance of conserved positively charged lysine residues in organic anion transporting polypeptide 1B3. Mol Pharmacol. 2011; 80(3):400-406. [PubMed: 21642393]

Marin JJ, Mangas D, Martinez-Diez MC, El-Mir MY, Briz O, Serrano MA. Sensitivity of bile acid transport by organic anion-transporting polypeptides to intracellular $\mathrm{pH}$. Biochim Biophys Acta. 2003; 1611:249-257. [PubMed: 12659967]

Martinez-Becerra P, Briz O, Romero MR, Macias RI, Perez MJ, Sancho-Mateo C, et al. Further characterization of the electrogenicity and $\mathrm{pH}$ sensitivity of the human organic anion-transporting polypeptides OATP1B1 and OATP1B3. Mol Pharmacol. 2011; 79(3):596-607. [PubMed: 21173039]

Meier-Abt F, Mokrab Y, Mizuguchi K. Organic anion transporting polypeptides of the OATP/SLCO superfamily: identification of new members in nonmammalian species, comparative modeling and a potential transport mode. J Membr Biol. 2005; 208(3):213-227. [PubMed: 16648940]

Mengs U, Pohl RT, Mitchell T. Legalon(R) SIL: the antidote of choice in patients with acute hepatotoxicity from amatoxin poisoning. Curr Pharm Biotechnol. 2012; 13(10):1964-1970. [PubMed: 22352731]

Meyer Zu Schwabedissen HE, Bottcher K, Chaudhry A, Kroemer HK, Schuetz EG, Kim RB. Liver X receptor alpha and farnesoid $\mathrm{X}$ receptor are major transcriptional regulators of OATP1B1. Hepatology. 2010; 52(5):1797-1807. [PubMed: 20827719]

Meyer zu Schwabedissen HE, Kim RB. Hepatic OATP1B transporters and nuclear receptors PXR and CAR: interplay, regulation of drug disposition genes, and single nucleotide polymorphisms. Mol Pharm. 2009; 6(6):1644-1661. [PubMed: 19558188]

Milne JL, Borgnia MJ, Bartesaghi A, Tran EE, Earl LA, Schauder DM, et al. Cryo-electron microscopy--a primer for the non-microscopist. FEBS J. 2013; 280(1):28-45. [PubMed: 23181775]

Min AD, Johansen KL, Campbell CG, Wolkoff AW. Role of chloride and intracellular pH on the activity of the rat hepatocyte organic anion transporter. J Clin Invest. 1991; 87(5):1496-1502. [PubMed: 2022722]

Mittur A, Wolkoff AW, Kaplowitz N. The thiol sensitivity of glutathione transport in sidedness-sorted basolateral liver plasma membrane and in Oatp1-expressing HeLa cell membrane. Mol Pharmacol. 2002; 61(2):425-435. [PubMed: 11809868]

Miyagawa M, Maeda K, Aoyama A, Sugiyama Y. The eighth and ninth transmembrane domains in organic anion transporting polypeptide 1B1 affect the transport kinetics of estrone-3-sulfate and estradiol-17beta-D-glucuronide. J Pharmacol Exp Ther. 2009; 329(2):551-557. [PubMed: 19244099]

Moore RJ, Jackson KG, Minihane AM. Green tea (Camellia sinensis) catechins and vascular function. Br J Nutr. 2009; 102(12):1790-1802. [PubMed: 19751534] 
Mukerjee P, Ostrow JD. Review: Bilirubin pKa studies: new models and theories indicate high pKa values in water, dimethylformamide and DMSO. BMC Biochem. 2010; 11:16. [PubMed: 20350305]

Nakanishi T, Tamai I. Genetic polymorphisms of OATP transporters and their impact on intestinal absorption and hepatic disposition of drugs. Drug Metab Pharmacokinet. 2012; 27(1):106-121. [PubMed: 22185815]

Niemi M. Transporter pharmacogenetics and statin toxicity. Clin Pharmacol Ther. 2010; 87(1):130 133. [PubMed: 19890253]

Niemi M, Pasanen MK, Neuvonen PJ. Organic Anion Transporting Polypeptide 1B1: a Genetically Polymorphic Transporter of Major Importance for Hepatic Drug Uptake. Pharmacol Rev. 2011; 63:157-181. [PubMed: 21245207]

Noe B, Hagenbuch B, Stieger B, Meier PJ. Isolation of a multispecific organic anion and cardiac glycoside transporter from rat brain. Proc Natl Acad Sci U S A. 1997; 94(19):10346-10350. [PubMed: 9294213]

Noe J, Portmann R, Brun ME, Funk C. Substrate-dependent drug-drug interactions between gemfibrozil, fluvastatin and other organic anion-transporting peptide (OATP) substrates on OATP1B1, OATP2B1, and OATP1B3. Drug Metab Dispos. 2007; 35(8):1308-1314. [PubMed: 17470528]

Nozawa T, Imai K, Nezu J, Tsuji A, Tamai I. Functional characterization of pH-sensitive organic anion transporting polypeptide OATP-B in human. J Pharmacol Exp Ther. 2004; 308:438-445. [PubMed: 14610227]

Obaidat A, Roth M, Hagenbuch B. The expression and function of organic anion transporting polypeptides in normal tissues and in cancer. Annu Rev Pharmacol Toxicol. 2012; 52:135-151. [PubMed: 21854228]

Petzinger E, Joppen C, Frimmer M. Common properties of hepatocellular uptake of cholate, iodipamide and antamanide, as distinct from the uptake of bromosulfophthalein. Naunyn Schmiedebergs Arch Pharmacol. 1983; 322(2):174-179. [PubMed: 6688124]

Pizzagalli F, Varga Z, Huber RD, Folkers G, Meier PJ, St-Pierre MV. Identification of steroid sulfate transport processes in the human mammary gland. J Clin Endocrinol Metab. 2003; 88(8):39023912. [PubMed: 12915686]

Ramachandran A, Betts G, Bhana S, Helme G, Blick C, Moller-Levet C, et al. An in vivo hypoxia metagene identifies the novel hypoxia inducible factor target gene SLCO1B3. Eur J Cancer. 2013; 49(7):1741-1751. [PubMed: 23352438]

Roth M, Obaidat A, Hagenbuch B. OATPs, OATs and OCTs: The organic anion and cation transporters of the SLCO and SLC22A gene superfamilies. Br J Pharmacol. 2012; 165:12601287. [PubMed: 22013971]

Roth M, Timmermann BN, Hagenbuch B. Interactions of green tea catechins with organic aniontransporting polypeptides. Drug Metab Dispos. 2011; 39(5):920-926. [PubMed: 21278283]

Satlin LM, Amin V, Wolkoff AW. Organic anion transporting polypeptide mediates organic anion/ HCO3-exchange. J Biol Chem. 1997; 272(42):26340-26345. [PubMed: 9334206]

Scharschmidt BF, Waggoner JG, Berk PD. Hepatic organic anion uptake in the rat. J Clin Invest. 1975; 56(5):1280-1292. [PubMed: 1184749]

Schodel J, Mole DR, Ratcliffe PJ. Pan-genomic binding of hypoxia-inducible transcription factors. Biol Chem. 2013; 394(4):507-517. [PubMed: 23324384]

Schrem H, Klempnauer J, Borlak J. Liver-enriched transcription factors in liver function and development. Part I: the hepatocyte nuclear factor network and liver-specific gene expression. Pharmacol Rev. 2002; 54(1):129-158. [PubMed: 11870262]

Segawa M, Ogura J, Seki S, Itagaki S, Takahashi N, Kobayashi M, et al. Rapid stimulating effect of the antiarrhythmic agent amiodarone on absorption of organic anion compounds. Drug Metab Pharmacokinet. 2013; 28(3):178-186. [PubMed: 22986710]

Shirasaka Y, Kuraoka E, Spahn-Langguth H, Nakanishi T, Langguth P, Tamai I. Species difference in the effect of grapefruit juice on intestinal absorption of talinolol between human and rat. $\mathrm{J}$ Pharmacol Exp Ther. 2010; 332(1):181-189. [PubMed: 19779132] 
Shirasaka Y, Mori T, Shichiri M, Nakanishi T, Tamai I. Functional pleiotropy of organic anion transporting polypeptide OATP2B1 due to multiple binding sites. Drug Metab Pharmacokinet. 2012; 27(3):360-364. [PubMed: 22201122]

Shirasaka Y, Suzuki K, Shichiri M, Nakanishi T, Tamai I. Intestinal absorption of HMG-CoA reductase inhibitor pitavastatin mediated by organic anion transporting polypeptide and Pglycoprotein/multidrug resistance 1. Drug Metab Pharmacokinet. 2011; 26(2):171-179. [PubMed: 21206133]

Shitara Y, Maeda K, Ikejiri K, Yoshida K, Horie T, Sugiyama Y. Clinical significance of organic anion transporting polypeptides (OATPs) in drug disposition: their roles in hepatic clearance and intestinal absorption. Biopharm Drug Dispos. 2013; 34(1):45-78. [PubMed: 23115084]

Singh BN, Shankar S, Srivastava RK. Green tea catechin, epigallocatechin-3-gallate (EGCG): mechanisms, perspectives and clinical applications. Biochem Pharmacol. 2011; 82(12):18071821. [PubMed: 21827739]

Sissung TM, Reece KM, Spencer S, Figg WD. Contribution of the OATP1B subfamily to cancer biology and treatment. Clin Pharmacol Ther. 2012; 92(5):658-660. [PubMed: 23010650]

Sreedharan S, Stephansson O, Schioth HB, Fredriksson R. Long evolutionary conservation and considerable tissue specificity of several atypical solute carrier transporters. Gene. 2011; 478(12):11-18. [PubMed: 21044875]

Stieger B, Geier A. Genetic variations of bile salt transporters as predisposing factors for drug-induced cholestasis, intrahepatic cholestasis of pregnancy and therapeutic response of viral hepatitis. Expert Opin Drug Metab Toxicol. 2011; 7(4):411-425. [PubMed: 21320040]

Stieger B, Heger M, de Graaf W, Paumgartner G, van Gulik T. The emerging role of transport systems in liver function tests. Eur J Pharmacol. 2012; 675(1-3):1-5. [PubMed: 22173125]

Stieger B, Meier PJ. Pharmacogenetics of drug transporters in the enterohepatic circulation. Pharmacogenomics. 2011; 12(5):611-631. [PubMed: 21619426]

Sugiura T, Otake T, Shimizu T, Wakayama T, Silver DL, Utsumi R, et al. PDZK1 regulates organic anion transporting polypeptide Oatp1a in mouse small intestine. Drug Metab Pharmacokinet. 2010; 25(6):588-598. [PubMed: 21084765]

Sugiura T, Shimizu T, Kijima A, Minakata S, Kato Y. PDZ adaptors: their regulation of epithelial transporters and involvement in human diseases. J Pharm Sci. 2011; 100(9):3620-3635. [PubMed: 21538352]

Sugiyama D, Kusuhara H, Shitara Y, Abe T, Sugiyama Y. Effect of 17 beta-estradiol-D-17 betaglucuronide on the rat organic anion transporting polypeptide 2-mediated transport differs depending on substrates. Drug Metab Dispos. 2002; 30(2):220-223. [PubMed: 11792694]

Sugiyama Y, Yamashita S. Impact of microdosing clinical study -- why necessary and how useful? Adv Drug Deliv Rev. 2011; 63(7):494-502. [PubMed: 20950660]

Sun AQ, Ponamgi VM, Boyer JL, Suchy FJ. Membrane trafficking of the human organic aniontransporting polypeptide C (hOATPC). Pharm Res. 2008; 25(2):463-474. [PubMed: 17641954]

Svoboda M, Riha J, Wlcek K, Jaeger W, Thalhammer T. Organic anion transporting polypeptides (OATPs): regulation of expression and function. Curr Drug Metab. 2011; 12(2):139-153. [PubMed: 21395542]

Tamai I, Nozawa T, Koshida M, Nezu J, Sai Y, Tsuji A. Functional characterization of human organic anion transporting polypeptide B (OATP-B) in comparison with liver-specific OATP-C. Pharm Res. 2001; 18:1262-1269. [PubMed: 11683238]

Tell R, Wang QT, Blunier A, Benya RV. Identification of ChIP-seq mapped targets of HP1beta due to bombesin/GRP receptor activation. Clin Epigenetics. 2011; 2(2):331-338. [PubMed: 22704345]

Tweedie D, Polli JW, Berglund EG, Huang SM, Zhang L, Poirier A, et al. Transporter studies in drug development: experience to date and follow-up on decision trees from the International Transporter Consortium. Clin Pharmacol Ther. 2013; 94(1):113-125. [PubMed: 23588318]

Van Beers BE, Pastor CM, Hussain HK. Primovist, Eovist: what to expect? J Hepatol. 2012; 57(2): 421-429. [PubMed: 22504332]

van Montfoort JE, Hagenbuch B, Groothuis GM, Koepsell H, Meier PJ, Meijer DK. Drug uptake systems in liver and kidney. Curr Drug Metab. 2003; 4(3):185-211. [PubMed: 12769665] 
Varma MV, Rotter CJ, Chupka J, Whalen KM, Duignan DB, Feng B, et al. pH-sensitive interaction of HMG-CoA reductase inhibitors (statins) with organic anion transporting polypeptide 2B1. Mol Pharm. 2011; 8(4):1303-1313. [PubMed: 21710988]

Vega-Hissi EG, Estrada MR, Lavecchia MJ, Pis Diez R. Computational chemical analysis of unconjugated bilirubin anions and insights into pKa values clarification. J Chem Phys. 2013; 138(3):035101. [PubMed: 23343304]

Visentin M, Chang MH, Romero MF, Zhao R, Goldman ID. Substrate-and pH-specific antifolate transport mediated by organic anion-transporting polypeptide 2B1 (OATP2B1-SLCO2B1). Mol Pharmacol. 2012; 81(2):134-142. [PubMed: 22021325]

Wang P, Hata S, Xiao Y, Murray JW, Wolkoff AW. Topological assessment of oatp1a1: a 12transmembrane domain integral membrane protein with three N-linked carbohydrate chains. Am J Physiol Gastrointest Liver Physiol. 2008; 294(4):G1052-1059. [PubMed: 18308854]

Wang P, Wang JJ, Xiao Y, Murray JW, Novikoff PM, Angeletti RH, et al. Interaction with PDZK1 is required for expression of organic anion transporting protein $1 \mathrm{~A} 1$ on the hepatocyte surface. $\mathrm{J}$ Biol Chem. 2005; 280(34):30143-30149. [PubMed: 15994332]

Wang WJ, Murray JW, Wolkoff AW. Oatp1a1 Requires PDZK1 to Traffic to The Plasma Membrane by Selective Recruitment of Microtubule-based Motor Proteins. Drug Metab Dispos. 2013

Wang X, Wolkoff AW, Morris ME. Flavonoids as a novel class of human organic anion-transporting polypeptide OATP1B1 (OATP-C) modulators. Drug Metab Dispos. 2005; 33(11):1666-1672. [PubMed: 16081670]

Weaver YM, Hagenbuch B. Several conserved positively charged amino acids in OATP1B1 are involved in binding or translocation of different substrates. J Membr Biol. 2010; 236(3):279-290. [PubMed: 20821001]

Weil G, Frimmer M. Effect of silymarin on the isolated perfused rat liver poisoned by phalloidin. Arzneimittelforschung. 1970; 20(6):862-863. [PubMed: 5468908]

Wlcek K, Koller F, Ferenci P, Stieger B. Hepatocellular organic anion-transporting polypeptides (OATPs) and multidrug resistance-associated protein 2 (MRP2) are inhibited by silibinin. Drug Metab Dispos. 2013; 41(8):1522-1528. [PubMed: 23695864]

Xiao Y, Nieves E, Angeletti RH, Orr GA, Wolkoff AW. Rat organic anion transporting protein 1A1 (Oatp1a1): purification and phosphopeptide assignment. Biochemistry. 2006; 45(10):3357-3369. [PubMed: 16519530]

Yamaguchi H, Sugie M, Okada M, Mikkaichi T, Toyohara T, Abe T, et al. Transport of estrone 3sulfate mediated by organic anion transporter OATP4C1: estrone 3-sulfate binds to the different recognition site for digoxin in OATP4C1. Drug Metab Pharmacokinet. 2010; 25(3):314-317. [PubMed: 20610891]

Yao J, Hong W, Huang J, Zhan K, Huang H, Hong M. N-Glycosylation dictates proper processing of organic anion transporting polypeptide 1B1. PLoS One. 2012; 7(12):e52563. [PubMed: 23285087]

Zair ZM, Eloranta JJ, Stieger B, Kullak-Ublick GA. Pharmacogenetics of OATP (SLC21/SLCO), OAT and OCT (SLC22) and PEPT (SLC15) transporters in the intestine, liver and kidney. Pharmacogenomics. 2008; 9(5):597-624. [PubMed: 18466105]

Zhang L, Huang SM, Lesko LJ. Transporter-mediated drug-drug interactions. Clin Pharmacol Ther. 2011; 89(4):481-484. [PubMed: 21423238]

Zhang L, Strong JM, Qiu W, Lesko LJ, Huang SM. Scientific perspectives on drug transporters and their role in drug interactions. Mol Pharm. 2006; 3(1):62-69. [PubMed: 16686370]

Zhang L, Zhang YD, Strong JM, Reynolds KS, Huang SM. A regulatory viewpoint on transporterbased drug interactions. Xenobiotica. 2008; 38(7-8):709-724. [PubMed: 18668428]

Zhang Y, Hays A, Noblett A, Thapa M, Hua DH, Hagenbuch B. Transport by OATP1B1 and OATP1B3 enhances the cytotoxicity of epigallocatechin 3-O-gallate and several quercetin derivatives. J Nat Prod. 2013; 76(3):368-373. [PubMed: 23327877]

Zhou F, Lee AC, Krafczyk K, Zhu L, Murray M. Protein kinase C regulates the internalization and function of the human organic anion transporting polypeptide 1A2. Br J Pharmacol. 2011; 162(6):1380-1388. [PubMed: 21133891] 
Ziegler K, Frimmer M, Fasold H. Further characterization of membrane proteins involved in the transport of organic anions in hepatocytes. Comparison of two different affinity labels: $4,4^{\prime}$ diisothiocyano-1,2-diphenylethane-2,2' -disulfonic acid and brominated taurodehydrocholic acid. Biochim Biophys Acta. 1984; 769(1):117-129. [PubMed: 6691970]

Zolk O, Schnepf R, Muschler M, Fromm MF, Wendler O, Traxdorf M, et al. Transporter gene expression in human head and neck squamous cell carcinoma and associated epigenetic regulatory mechanisms. Am J Pathol. 2013; 182(1):234-243. [PubMed: 23137910] 


\section{Table 1}

\section{Substrate classes of human OATPs}

\begin{tabular}{|c|c|c|c|}
\hline OATP & Endogenous substrates & Xenobiotic substrates & Model substrates \\
\hline OATP1A2 & $\begin{array}{l}\text { bile salts, bilirubin, steroid hormone } \\
\text { metabolites, thyroid hormones and } \\
\text { metabolites, }\end{array}$ & $\begin{array}{l}\text { liver function markers, } \beta \text {-blockers, } \\
\text { statins, antiviral drugs, antibiotics, } \\
\text { mushroom toxins, neuropeptides, } \\
\text { anticancer drugs }\end{array}$ & $\begin{array}{l}\text { Bromosulfophthalein } \\
\text { Estrone-3-sulfate } \\
\text { Fexofenadine }\end{array}$ \\
\hline OATP1B1 & $\begin{array}{l}\text { bile salts, bilirubin, steroid hormone } \\
\text { metabolites, thyroid hormones and } \\
\text { metabolites, inflammatory mediators }\end{array}$ & $\begin{array}{l}\text { liver function markers, mushroom } \\
\text { toxins, statins, sartanes, antibiotics, } \\
\text { antiviral drugs, anticancer drugs }\end{array}$ & $\begin{array}{l}\text { Bromosulfophthalein } \\
\text { Estradiol-17 } \beta \text {-glucuronide } \\
\text { Estrone-3-sulfate } \\
\text { Pitavastatin } \\
\text { Atorvastatin } \\
\text { Pravastatin } \\
\text { Rosuvastatin } \\
\text { Valsartan }\end{array}$ \\
\hline OATP1B3 & $\begin{array}{l}\text { bile salts, bilirubin, steroid hormone } \\
\text { metabolites, thyroid hormones, inflammatory } \\
\text { mediators }\end{array}$ & $\begin{array}{l}\text { liver function markers, mushroom } \\
\text { toxins, statins, sartanes, antibiotics, } \\
\text { antiviral drugs, anticancer drugs, } \\
\text { peptides }\end{array}$ & $\begin{array}{l}\text { Bromosulfophthalein } \\
\text { Cholecystokinin octapeptide } \\
\text { Estradiol-17 } \beta \text {-glucuronide } \\
\text { Valsartan }\end{array}$ \\
\hline OATP1C1 & $\begin{array}{l}\text { thyroid hormones and metabolites, steroid } \\
\text { hormone metabolites }\end{array}$ & liver function markers & Thyroxine \\
\hline OATP2A1 & inflammatory mediators & & $\begin{array}{l}\text { Prostaglandines }\left(\mathrm{PGE}_{1}, \mathrm{PGE}_{2} \text {, }\right. \\
\left.\mathrm{PGE}_{2 \mathrm{a}}\right)\end{array}$ \\
\hline OATP2B1 & $\begin{array}{l}\text { steroid hormone metabolites, inflammatory } \\
\text { mediators, thyroid hormones }\end{array}$ & liver function markers, statins, & $\begin{array}{l}\text { Bromosulfophthalein } \\
\text { Estron-3-sulfate }\end{array}$ \\
\hline OATP3A1 & $\begin{array}{l}\text { steroid hormone metabolites, inflammatory } \\
\text { mediators, thyroid hormones }\end{array}$ & & $\begin{array}{l}\mathrm{PGE}_{1} \\
\mathrm{PGE}_{2}\end{array}$ \\
\hline OATP4A1 & $\begin{array}{l}\text { bile salts, steroid hormone metabolites, } \\
\text { thyroid hormones, }\end{array}$ & & $\begin{array}{l}\text { Triiodothyronine } \\
\text { Taurocholate }\end{array}$ \\
\hline OАTP4C1 & $\begin{array}{l}\text { bile salts, steroid hormone metabolites, } \\
\text { thyroid hormones }\end{array}$ & & $\begin{array}{l}\text { Estrone-3-sulfate } \\
\text { Digoxin }\end{array}$ \\
\hline
\end{tabular}

For a detailed recommendation of OATP probe substrates and inhibitors, please refer to: (Brouwer et al., 2013) 
